\title{
THE ALIEN AND THE PUBLIC CHARGE CLAUSES
}

\author{
LEO M. ALPERT †
}

"These questions have faced us before; in our generation they have come before us continuously since the War. Russians, Armenians, Greeks and others have succeeded one another as the refugee begging consideration and a home. Today it is the German. Tomorrow it may be the Spaniard. After that, who? Ours must be a policy based on understanding and appraisal, devoid of emotionalism and partisanship."

\section{FIELDS, The Refugee in the United States}

Traditionally, the United States of America has considered itself a haven of refuge for the oppressed of other lands. That this humanitarian tradition fitted the economic needs of an expanding country has been regarded by some as a happily providential coincidence and by others as signal hypocrisy. But with episodic economic crises stripping native born and resident alien millions of their livelihood, the tradition of asylum began to fade. When the making in Europe of what is known as "history" caused "mass immigration"1 of those who took seriously the words on the base of the Statue of Liberty, the two attitudes were brought into even sharper opposition. So it is that today one of the bogeymen haunting these immigrants and the organizations assisting them emanates from the "public charge" clauses of Sections 3 and 19 of the Immigration Act.

Section 3 ungrammatically excludes from admission into the United States "persons likely to become a public charge;"' Section 19 would

$\dagger$ Member of Maryland Bar. Acknowledgements are due Louise A. Alpert, now of the Refugee Adjustment Committee, Inc., of Baltimore, Maryland, for suggestions, aid, and insight concerning many of the problems created by the public charge clauscs. The conclusions, however, are the writer's responsibility.

1. The common opinion of "mass immigration," a horde of alicns clamoring for entry into the United States and inundating it, is not at one with the facts. The quota for all countries, as fixed by President Hoover's Proclamation of March 22, 1929, is 153,714 immigrants a year. The number of immigrants actually admitted under the quota each year, beginning with 1931 and ending through 1938 , is: 51,$153 ; 12,022 ; 7,634$; 11,$719 ; 16,325 ; 17,732 ; 26,654 ; 42,685$. See Fietds, The Refugee in the United States (1938) 9, 20-21; A arerican Friends Service Committee, Refugee Facts (1939) 6-7. It is stated in the latter pamphlet that, for the six years from July 1, 1932, through June 30, 1938, 241,962 immigrants were admitted to the United States for permanent residence and that, in the same period 246,449 immigrants previously admitted to the United States for permanent residence moved away. With respect to Nazi Germany, however, there has been an increase. German immigrants in the six and a half years from July 1, 1932, through December 30,1938 , totalled 65,404 ; during the same period, 22,362 aliens in this country left for Germany. Thus in the six and one-half years, there has been an increase of 43,042 German aliens, an average per annum of 6,622 . This is so small a number that the clamor is either plain foolishness or vicious talk.

2. 39 STAT. 875 (1917), 8 U. S. C. $\S 136$ (1934). 
deport those aliens who, within five years after entry, become public charges "from causes not affirmatively shown to have arisen subsequent to landing." 3 The two clauses must be carefully discriminated.

Section 3 deals with inadmissibility of an alien at time of attempted entry; such inadmissible aliens who nevertheless enter this country may be deported only if taken into custody within five years of entry. ${ }^{4}$ Section 19 may be invoked at any time and any alien deported who, within five years of entry, actually becomes a public charge.

The word "entry," by way of further scene setting, is literally construed. Any return to the United States, be the departure ever so slight, is an "entry." The reports are spangled with cases in which the Immigration Service has forced this accepted judicial attitude in order to deport an alien who, at time of original entry, was inadmissible but somehow got into the country, stayed over five years - hence could not be deported - and then visited Canada or Mexico, or sailed on a ship touching a foreign port, or went from one point in the United States to another on a train which wandered over the border and back, to be seized on "return" by the Service which is remarkably astute in such matters." The same activity is manifested in cases where the alien at time of original entry was admissible but would not be permitted to reenter the country if he left; and the visit to Canada. to Mexico, or the touching at a foreign port, or the unknown train crossing, is uniformly held a departure not entitling the alien to return to this land of freedom and opportunity. ${ }^{8}$

3. 39 STAT. $\$ \$ 9$ (1917), 8 U. S. C. $\$ 155$ (1934).

4. Cook and Hagerty, Imsigration Laws of the Umited St.utes (1929) \$23\$.

5. Ibid.

6. There is some dispute in the cases, depending on the facts, but with that caveat the statement as made is correct. United States ex rel. Volpe v. Smith, 289 U. S. 422, 425 (1933); United States ex rel. Claussen v. Day, 279 U. S. 398 (1929); Zurbricl: v. Woodhead, $90 \mathrm{~F}$. (2d) 991,991 (C. C. A. 6th, 1937): "Once more we are impslled to direct attention to the toll in human anguish which so often follows that literal reading of the Immigration Act by which every departure from the United States, hovever brief and temporary, and pursuant to no intention to relinquish domicile, constitutes subsequent return a new entry, subjecting the unsuspecting to exclusion or deportation." Schmud:cr v. Miartinez, 37 F. (2d) 315,316 (C. C. A. 4th, 1930).

7. Hansen r. Haff, 291 U. S. 559 (1934); see note 6, supro, and Zurbricls v. Borg, 47 F. (2d) 690 (C. C. A. 6th, 1931); United States v. Williams, 187 Fed. 470 (S. D. N. Y., 1911).

S. United States $e x$ rel. Medich v. Burmaster, 24 F. (2d) 57 (C. C. A. Sth, 1923); Guimond v. Howes, 9 F. (2d) 412 (S. D. Me, 1925); Ex farte Horn, 292 Fed. 455 (N. D. Wash., 1923) ; Ex parte Fragoso, 11 F. (2d) 988 (S. D. Calif., 1926); Ex farie Rodriguez, 15 F. (2d) 878 (S. D. Tex, 1926); United States ex rcl. Lehtola v. Mlagie, 47 F. (2d) 768 (D. Minn., 1931) and cases cited supra notes 6 and 7. 
I.

Who Is A Public Charge?

“. . . and, without in the least intending necessarily to impose such a sociological purpose upon the classification of Congress, I believe that the statute should be reasonably construed . . ." Judge Learned Hand

"Public charge" has been defined as any maintenance or financial assistance rendered from public funds or funds secured by taxation. "It does not mean the acceptance of charitable help of any individual or organization when such funds are secured by voluntary contributions, or for maintenance in any institution supported by donations and not receiving a part or all of its support from public (tax) funds." 10

The phrase is ringed with the emotional aura of paupers and charity and almshouses, but, despite the brave statement above, the federal courts, on at least one point, are in a most violent disagreement unalloyed as yet by the Supreme Court.

\section{The Alien Who Has Served A Jail Term?}

The major battle of the circuits is over this question: whether an alien, sentenced to jail here, who must perforce, for the period of his incarceration, be maintained by the state out of public funds, is thereby a public charge. To the alien, the importance of the answer need hardly be stated. A chance encounter with Blue Laws, with a roadside Justice of the Peace operating a speed trap, are but minor instances of the ease with which entry into jail may be effected.

In the First Circuit, the District Court for Massachusetts, without passing directly upon the question, expressed doubt anent the soundness of an affirmative answer $;^{11}$ but two later cases, from the District Court for Maine, in 1925 and 1926, seemed to feel an affirmative answer was correct. $^{12}$

Probably this was influenced by one of the earliest cases on the point, a New York district court decision in 1910 which held flatly that inmates of prisons "were surely public charges, at least during the terms of their incarceration." 13 Some seven years later, however, the Circuit Court of Appeals for the Second Circuit took the contrary view:

9. Cook and Hagerty, Imamigration Laws of the United States (1929) §285.

10. Ibid.

11. Ex parte Costarelli, 295 Fed. 217 (D. Mass., 1924).

12. Ex parte Riley, 17 F. (2d) 646 (N. D. Me., 1926); Guimond v. Howes, 9 F. (2d) 412 (S. D. Me., 1925).

13. United States ex rel. Freeman v. Williams, 175 Fed. 274, 275 (S. D. N. Y., 1910). 
"We are convinced that Congress meant under the act to exclude persons who were likely to become occupants of almshouses for want of means with which to support themselves in the future. If the word covered jails, hospitals, and insane asylums, several of the other categories of exclusion [which specifically deal with such subjects ${ }^{14}$ ] would seem to be unnecessary."15

The New York district, nonetheless, followed its former ruling with bland unconcern, ${ }^{16}$ and even seemed to have affected the circuit court ${ }^{17}$ until that court spoke to the question again in 1929.18 "The language ... " said Judge Learned Hand, referring to the public charge statute, "suggests rather dependency than imprisonment." 10

In the remaining circuits where the question has arisen, the decisions are equally and hopelessly conflicting, ${ }^{20}$ so that until the Supreme Court has spoken, and possibly even after, the alien's rights, to put it vulgarly,

14. In addition to the public charge clauses the Statute contains these: "idiots," "imbeciles," "epileptics," "insane persons," "professional beggars," "vagrants," "prostitutes," aliens sentenced to prison for a specified term for a crime involving moral turpitude, and a host of other categories of exclusion and denortation.

15. Howe v. United States $c x$ rel. Savitsky, 247 Fed. 292, 294 (C. C. A. 2d, 1917).

16. Ex parte Mitchell, 256 Fed. 229 (N. D. N. Y.. 1919).

17. United States ex rel. Mantler v. Comm'r, 3 F. (2d) 234 (C. C. A. 2d, 1924); Wallis v. United States c.t rel. Mannara, 273 Fed. 509 (C. C. A. 2d, 1921).

18. United States $c x$ rcl. Iorio v. Day, 34 F. (2d) 920 (C. C. 1. 2d, 1929).

19. Id. United States ex rel. Iorio v. Day, 34 F. (2d) 920, 922 (C. C. A. 2d, 1929 ).

20. The Third, Fourth, Seventh and Tenth Circuits have not had oceasion to decide the question. In the Fifth Circuit, a District Court case by implication tool the affirmstive. Ex parte Rodriguez, 15 F. (2d) $\$ 78$ (S. D. Tex., 192i). But the Circuit Court, one year later, in 1927, said emphatically that public charge cannot be sunpused to refer to anything other than "a condition of dependence on the public for support. Nothing in the act indicates that in using the words in question the lawmakers had in mind the subject of criminal misconduct or the consequences thereof." Coykendall v. Slsrmetta, 22 F. (2d) 120,121 (C. C. A. 5th, 1927). The Sixth Circuit in an early case toik the view of the New York District Court that "inmates of jails and prisons are fur the time liaing public charges." Sam Fung Yen v. Frick, 233 Fed. 393, 396 (C. C. A. 6th, 1916), ecrt. denied, 242 U. S. 642 (1916). Then, in 1930, without actually overruling its iormer view, the court held the principle inapplicable to the particular case before it and went on to say that the negative answer to the question was supported by the better authority and the stronger reason. Brown v. Zurbrick, 45 F. (2d) 931 (C.C.A. 6th, 1930). The Eighth Circuit has consistently, if such a word can be used to refer to only two cases, uriteld the affirmative of the question. United States ex rel. Medich v. Burmaster, 24 F. (2d) 57 (C. C. A. Sth, 1928) ; United States ex rel. Lehtola v. Magie, 47 F. (2d) 768 (D. Minn., 1931). The Ninth Circuit presents the amusing spectacle of the circuit court standing on the negative, $\mathrm{Ng}$ Fung Ho v. White, 266 Fed. 765 (C. C. A. 9th, 1920), ccrt. granted, 254 U. S. 628 (1920), affirmed in part and recersed in part ailhout consideration of the public charge issue, 259 U. S. 276 (1922), with all the later district cuurt decisions, for Washington and California, taking the affirmative. Ex farte Tsunetaro Mrachida, 277 Fed. 239 (W. D. Wash., 1921) ; Ex parte Horn, 292 Fed. 455 (W. D. Wash., 1923) ; Ex partc Reeves, 292 Fed. 766 (W. D. Wash., 1923); Ex fartc Britten, 293 Fud. G1 (W. D. Wash., 1923) ; Ex parte Fragoso, 11 F. (2d) 988 (S. D. Calif., 1920). 
will turn upon the place where he is caught by the Immigration Service. There is nonetheless discernible a trend toward removing criminal misconduct from the public charge category. ${ }^{21}$ But that may be cold comfort to the deported Arkansas alien, for example, who sees his fellow in Mississippi, just across the state line, go off scot-free under a federal statute supposed to be operating uniformly over the states. A disquisition on the American system of laws and government should then be of consuming awe to the alien.

\section{What Is Public Assistance?}

Until the mid nineteen-thirties a prevailing climate of opinion considered relief a degrading charity. Relief today is still felt to be some excrescence on the social order but nonetheless a responsibility and duty of society. With this growth of attitude the function has been expanded. It is now because of the diversity in the types of public assistance that the public charge spectre is so fearsome. The difficulties illustrate the frequent clash between society in flux and law in hysteresis. The society of 1939 is here controlled by a set of statutes which have not been thoroughly examined, judging by their motley physical appearance, since 1924; and piecemeal added to or altered since that time. The social drives of 1939 bear the same relationship to those of 1924 as an adolescent to a mewling infant.

Even so it is curious that the reports are so singularly sparse of cases dealing directly with the general statement that aliens supported in whole or in part by public (tax) funds are deportable as public charges. The facts in Guimond v. Howes ${ }^{22}$ showed a Canadian alien husband in jail for liquor law violations with his alien wife and citizen (by birth) children being cared for by the township in which the family had lived for years. Ex parte Turner ${ }^{23}$ involved an alien Canadian supported by "charitable relief" while her husband was a free hospital patient. In re Osterloh $^{24}$ dealt with a German girl living at the Gulf Coast Home, apparently a charitable institution for those young ladies who are more to be pitied than censured. In none of these cases, though the ground is clear, was the public charge clause applied. Only in two more recent decisions was deportation ordered squarely upon the fact that the aliens were supported by "welfare relief." ${ }^{25}$ And today, to return to the question

21. See Comment, Statutory Construction in Deportation Cases (1931) 40 YALE L. J. $1283,1292$.

22. 9 F. (2d) 412 (S. D. Me., 1925).

23. $10 \mathrm{~F}$. (2d) 816 (S. D. Calif., 1926), motion for leave to file habeas corpus and proceed in forma panperis denied, 275 U. S. 484 (1927).

24. 34 F. (2d) 223 (S. D. Tex., 1929).

25. Ex parte Nunez, 93 F. (2d) 41 (C. C. A. 9th, 1937), rev'g, 18 F. Supp. 1007 (S. D. Calif., 1937) ; United States ex rel. Matterazza v. Fogarty, 13 F. Supp. 403 (W. D. N. Y., 1936). 
of what is public assistance, such relief is just one facet of a many-sided social program.

Over the forty-eight states is spread a federal plan, administered by the states which also contribute funds, of aid to the blind, old age pensions, aid to dependent children, public health, and employment services. In almost every state there is state and local general public assistance (which goes by many different names: welfare relief, home relief, and so on), free hospital care, and dispensary service; there are state institutions for the tuberculous, the insane, the mentally defective; children's institutions for the feeble-minded, children's and adults' convalescent homes, state or local hospitals for infectious diseases, and state and local public health services.

In addition, for the employable destitute, there is the Works Progress Administration, the Civilian Conservation Corps, and the National Youth Administration. Public Works Administration is operated on a basis of merit rather than need - the need being considered only in relation to the municipalities seeking grants of P.W.A. funds - but might also be here included as bearing on the question of what type of public assistance will render an alien deportable. The recent changes in the law denying aliens any share in W.P.A. and P.W.A. ${ }^{20}$ does not affect the importance of treating those agencies, because it has been estimated that over 45,000 aliens were on W.P.A. alone before the change ${ }^{27}$ and many may have been in the United States less than five years.

It is the type of relief today usually called general public assistance, welfare relief, or home relief, that is the modern counterpart of the pauper, almshouse and charity concept. Many of the states have no citizenship qualifications for this relief although a varying length of residence within the state is required. Destitution is the basis of the grant. with varying restrictions on employability.

Even without the authority of the two cases holding deportable an alien supported by such a grant, the conclusion is inescapable that acceptance of this type of relief by an alien with less than five years residence within the United States would render him deportable as a public charge (subject to the proviso regarding a cause subsequent to landing). In general, this circumstance is clearly covered under present law though there may arise a number of perplexing cases.

For example, suppose a family on relief is composed of a citizen father, an alien mother, and alien children; or an alien father and mother and citizen (by birth) children; or some other of the possible combinations. Necessarily the alien members of the family also live on the relief monies. Are they deportable as public charges for receiving public funds?

26. 84 Cong. Rec, Jan. 13, 1939, at 465; see Alicn Legislation (1939) 7 InT. Junn. A. BUL. 126.

27. Alien Legislation (1939) 7 Int. JuRrd. A. BunL 12j. 
Since relief monies are budgeted to applicants on the size of the family unit, it would follow that, in practical effect, it is the aliens who are also applicants for, and recipients of, the public funds. There might seem a logical contradiction in the fact that the citizen husband is under a duty to support his family and hence an alien wife's insistence that the duty be performed should not cause deportation. This contradiction is not real. At bottom, since the amount given to the head of the family is determined by the size of the family, the aliens are direct recipients of the public relief. The point was not discussed in United States ex ral. Matterazza $v$. Fogarty ${ }^{28}$ but that case may be taken as athority for the stand. There the alien wife and citizen husband had unsuccessfully applied to the city of Rochester for relief twice in 1933 and twice in 1934. On the wife's return, later in 1934, from Italy, whence she had gone to bring back her son, born in Italy of her previous marriage to an Italian, she found her husband in jail charged with receiving stolen goods. She and the boy were then supported by the department of welfare of the city. A finding by the Immigration Service that she and the boy were inadmissible as likely to become public charges was sustained by the court.

Indeed, the courts have gone even further. An alien mother was ordered deported, though her three minor children were citizens by birth, because she had lived on the relief monies allotted to her and the children. ${ }^{29}$ The district court had written a strong opinion against deportation by arguing that the children were the major beneficiaries of the public funds, that sound public policy, based on the welfare of American children, demanded the mother's presence, and that, if the mother were deported, someone else would have to look after the children anyhow. ${ }^{80}$ But the sound sense of this decision was overruled by the pundits on the circuit court.

A consideration now of the other types of public assistance, beginning with that kind which least presents a ground for deportation, raises the question of the Public Works Administration.

Since P.W.A. funds go to cities or states showing need and are not calculated on the need of the individual employee - but on his merit there would seem to be little doubt that an alien who has worked for P.W.A. is not a public charge. There have been no cases on this point but the reasoning is clear enough.

A similarly clear situation is that of an alien child using public school facilities. Again no reported cases appear, but since education of the resident alien child is a matter of governmental concern, compulsory in

28. 13 F. Supp. 403 (W. D. N. Y., 1936).

29. In re Nunez, 93 F. (2d) 41 (C. C. A. 9th, 1937).

30. In re Nunez, 18 F. Supp. 1007 (S. D. Calif., 1937). 
most states, there is no question on attendance at such schools not being a ground for deportation.

A diverting parenthesis bolstering this position is the case of the resident alien boy accompanying his school class on a visit to Canada and on return being seized by the Immigration Service. Under habeas corpus the child was released, because, said a judge obliged to sharp-shoot his way through the entry cases - which supported the argument of the Service - the boy was obliged by law to go to school and was therefore compelled to accompany his class on pain of becoming a truant. Hence he could not be said to have left the country. The underlying basis of the entry cases is that of voluntary departure; this boy had been required to leave. ${ }^{31}$ If the element of compulsion - which in the public school situation is a short-hand expression for the idea that minor persons resident in the United States must be trained to become useful members of society - is carried so far in an entry case, there is little reason to suppose that the use of public school facilities would render the public charge clause operative.

This broad statement is complicated, nevertheless, by the existence of special classes and special schools for the "retarded" and defective child.

The transfer of an alien child from the usual classes in - say - Public School 67 to a special class in the school for the "retarded" pupils should not. in reason, and probably would not, cause the child to fall into the public charge category. But suppose the alien child is now moved one more step: from the special class to a state or city school for defective children. Is the child now a public charge?

The decision in Nocchi v. Johnson ${ }^{32}$ answered the question in the negative, but on a point entirely different from the one that might have been expected. Judge Anderson turned his opinion by arguing that since the parents were financially able to pay the costs at the Wrentham State School for Defective Children, and were duty bound to educate and maintain their boy, failure of the parents to pay and failure of the state to enforce payment did not, as a matter of law, make the boy a public charge. The state had not made a demand upon the parents to pay; their failure to do so, therefore, was not voluntary and hence was not an "acceptance" of public aid. This, say commentators, is the usual rule in hospital deportations. ${ }^{33}$

The School for Defective Children situation is thus here analogized to the hospital cases, which will be dealt with shortly as another type of

31. United States $e x$ rel. Valenti v. Karmuth, 1 F. Supp. 370,373 (X. D. N. Y., 1932).

32. Nocchi v. Johnson, 6 F. (2d) 1 (C. C. A. 1st, 1925).

33. See Cook and Hagerty, Immigration Laws of the Uivited States (1929) $\S 286$. 
public assistance. For the aptness of the analogy is questionable, and the failure to discriminate between the two kinds of cases may be dangerous.

First, there are many different schools for defective children: some are purely custodial institutions and so, in function, do resemble hospitals; others are schools in the highest and best sense of the word, training the child to make use of his limited abilities usually through instruction in the manual trades. The Wrentham School in Nocchi v. Johnson was, in fact, a real school of that latter kind and the alien boy was not so feeble-minded that he would have been unable to learn a trade and make a living at it.

Second, the rights involved in the school cases are those of the alien child. "It must not be overlooked," said Judge Anderson, "that the rights we are now dealing with are the rights of this boy. It was the legal duty of his parents, being able, to support and educate him. It was also the duty of the officers of the Commonwealth of Massachusetts to collect proper charges for his support and training in the Wrentham School, even if the parents were unwilling to pay these charges. Failure by his parents, or by the officers, or by both, in this duty does not subject the boy to the penalty of deportation." ${ }^{34}$

The first point of difference between the school and the hospital cases, however, would not seem to change the operation of the law. The existence of special schools for children ineligible for ordinary public schools necessitates only the further inquiry of whether the facilities are charged for or are free. If free, there is no difficulty. If charged for, the fact that such schools perform the function of the ordinary public schools does not alter the fact that an alien child attending the special school is an expense to the state. But the second point of difference - that it is the rights of the child which are involved - does, under the rule of Nocchi v. Johnson, enunciate a different principle: that the child is a public charge only if the parents are financially unable to pay the special costs. This liberal rule rings true because the training of the alien child to become a possibly useful citizen may be, to the state, worth the added administrative trouble of ascertaining whether the parents are financially responsible, instead of simply taking the fact for granted that the alien child at the special school is a public charge when the parents have not paid the expenses.

That reasoning is equally applicable to the hospital cases in which an alien child is the free patient.

Omitting an early New York district case which held deportable an Italian adult, who, after spending over $\$ 1,500$ for private medical services, was obliged to become a charity patient at Bellevue and was informed on by an enemy, ${ }^{35}$ the case of Ex parte Kichmiriantz is next

34. Nocchi v. Johnson, 6 F. (2d) 1, 2 (C. C. A. 1st, 1925).

35. United States ex rel. Canfora v. Williams, 186 Fed. 354 (S. D. N. Y., 1911). 
presented. ${ }^{36}$ There a young Armenian, committed to the state insane asylum, was held not deportable as a public charge. If, said District Judge Dooling cryptically, mere detention in a state hospital makies a person a public charge without consideration of the question whether or not the person is actually a public charge, then the order of deportation must be sustained. But, the judge continued, the law of California imposed the cost of maintaining an insane person on his estate and parents: "I am of the opinion that the words 'public charge' . . . mean just what they mean ordinarily: that is to say, a money charge upon, or an expense to, the public for support and care; and when the state receives from the relatives what it has fixed as an adequate compensation for such support, I do not think the individual so cared for is a public charge, within the meaning of the act." ${ }^{37}$ From this, Judge Dooling erected the presumption that, in the absence of an affirmative showing to the contrary, it must be presumed that the costs were borne by the legally responsible persons.

Though this presumption can hardly be said to be the "law," the trend is toward examination of the circumstances under which the alien became an inmate of a public institution. If the state received payment for its services as billed, though not the equivalent to the state of the cost, the public charge clause is held inoperative. ${ }^{3 s}$ If no billing was made, but the alien's relatives were willing to pay all along, the public charge clause again will not be applied, ${ }^{39}$ although this is not the weight of authority. On the basis of the trend it might be hazarded that unless billing has been made and payment refused the alien will not be held a public charge. Certainly this is a far more reasonable doctrine than the older one requiring the alien's relatives to take the initiative in asling for the hospital bills, although at present it is still a minority rule. Indeed, the

36. 283 Fed. 697 (N. D. Calif., 1922).

37. Ex parte Kichmiriantz, $2 \$ 3$ Fed. 697, 698 (N. D. Calif., 1922).

38. United States ex rel. Brugnoli v. Tod, 300 Fed. 913 (S. D. N. Y., 1923), aff'd. 300 Fed. 918 (C. C. A. 2d, 1924) on the ground that there was a lacl: of medieal cvidence that the psychosis from which the alien was suftering and for which she had tzen institutionalized could not have arisen subsequent to landing. Cf. Unitcd States cr rel. Mandel v. Day, 19 F. (2d) 520 (E. D. N. Y., 1927). Ex faric Orzceitowsla, 23 F. Sung. 428 (D. Ore., 1938) involved an alien girl whose prosperous uncles left money at the state hospital for her upkeep but not enough to cover the full costs of the girl's care; on the uncles' testimony that such failure was due to a misunderstanding and that titey were willing to pay all past and future charges, the habeas corpus writ was granted.

39. United States ex rel. Donatello v. Comm'r, 4 F. (2d) 808 (E. D. N. Y., 1925), rev'd on reargument, S F. (2d) 362 (E. D. N. Y., 1925), on the ground of mental cundition at time of entry; Ex parte Orzechowsks, 23 F. Supp. $42 S$ (D. Ore., 1938); sce also United States ex rel. Haft v. Tod, 300 Fed. 917 (S. D. N. Y., 1923), aff'd, 300 Fed. 918, 918 (C. C. A. 2d, 1924), where the judge dismissed the writ of habeas corpus on the ground that the alien was inadmissible at time of entry breause of his mental condition. 
confusion of these cases resembles the "law" applicable to the imprisoned alien.

Whether tender of payment after deportation proceedings have begun should be held to stop the execution of the warrant is a debatable issue. With logic, it is stated that in fact the alien has become a public charge and so must be deported. ${ }^{40}$ This is a harsh and literal logic. It is equally applicable to the situation above where the hospital does not ask for payment and the relatives do not offer payment, though they are quite willing to pay if asked. Yet the logic is not literally applied there. A more equitable enforcement of present law, safeguarding equally as well the interested community, would be the requirement of an investigation to ascertain the financial standing of the relatives, to learn whether past failure to pay was due to mistake or misunderstanding, and possibly to require that a public charge bond be posted. The purpose of the Immigration Laws is not really to avenge by deportation the acceptance of public care - although this seems to be the emotional level upon which the cases are litigated - but to protect the state. Until that purpose is acknowledged and the emotional attitude so shifted, it would appear that harsh and literal logic will continue to be the prevailing doctrine.

The principal types of public assistance have now been considered; other less important types are fitted rather obviously into one of these categories. It is therefore apposite to turn to the clause in the statute saving from deportation an alien who has become a public charge if he makes an affirmative showing that the canse for his status arose after his landing in the United States.

\section{Cause Subsequent To Entry}

Causality, in philosophy as in law, is a messy business. The accident, disease, and mental defect cases, because of a fairly well developed medical skill in etiology, present a method of approach.

In the case of the alien hit on the head by a brick, or run over by a train, the facts of themselves, to use a handy phrase, establish a cause subsequent to entry for the alien's free care at a hospital. Fairly clear also are those cases in which a slowly developing disease, such as tracoma, ${ }^{41}$ has a causality definite enough in point of time for a surgeon to state within reason the date of onset. In many of the dementia praecox cases physicians have asserted that the disease had its beginning in youth, and, on the basis of the particular clinical history, have diagnosed it as

40. See pp. 25-26, supra.

41. In Hughes v. United States ex rel. Licata, 295 Fed. 800 (C. C. A. 3d, 1924), a surgeon's certificate that an entry-seeking alien had tracoma was held insufficient for the stated reason that tracoma develops slowly and hence if the alien had tracoma at the time of landing she must have had it at the time of embarcation, and this last was denicd in the certificate. 
chronic, due to conditions existing prior to landing." The mental cases are difficult to generalize because of the almost invariable inclusion of the separate complaint under the Immigration Laws that the alien was a person of "constitutional psychopathic inferiority" at time of entry." Under this complaint it is for the Immigration Service to prove affirmatively the existence of the mental condition at the time of landing, st although with respect to the public charge clause it is for the alien to show affirmatively that the cause therefor arose after landing. The shifting of the evidentiary burdens in the cases where both complaints are preferred by the Service makes the decisions hard to construe. In addition, the psychoses are delicate concepts for liandling, as is made manifest by Ex parte La Matina ${ }^{45}$ and United Slates ex rel. Pozilozice v. $D a y .{ }^{46}$

In the first case, an Italian alien had entered the United States in 1909 and had left in 1915 to fight for his country in the World War. On his return to this country in 1920 he was at once committed to a state

42. Ex parte Kichmiriantz, $2 \$ 3$ Fed. 697 (N. D. Calif., 1922); United States $c x$ rel. Brugnoli v. Tod, 300 Fed. 913 (S. D. N. Y., 1923), aff'd (for lack of evidence that psychosis could not have arisen subsequent to landing), 300 Fed. 918 (C. C. A. 2d, 1924) ; United States $e x$ rel. Haft v. Tod, 300 Fed. 917 (S. D. N. Y.. 1923), aff'd, 360 Fed. 918 (C. C. A. 2d, 1924); E.r parte La Matina, o F. (2d) 468 (D. Conn., 1925); United States ex rel. Romanow v. Flymn, $17 \mathrm{I}$. (2d) 378 (W. D. X. Y., 1927); United States $e x$ rel. Powlowec v. Day, 33 F. (2d) 207 (C. C. A. 2d, 1929 ).

43. See cases cited supra note 42 and see United States c.x rel. Casimano v. Comm'r, 15 F. (2d) 555 (C. C. A. 2d, 1926); Lnited States ar rel. Mandel v. Day, 19 F. (2d) 520 (E. D. X. Y., 1927); United States a.t rol. Paulantunir v. Lay, 22 F. (2d) 914 (C. C. A. 2d, 1927); Foley cx rel. Schenck v. Ward. 13 IF. Sulp. 915 (D. Alass., 1935); Ex parte Orzechowska, 23 F. Supp. 423 (D. Ore., 19381. The "constitutional psychopathic inferiority" clause is contained in Section 3 of the Immigration Act of 1917, 39 StAT. 875 (1917), \& U.S. C. \$136 (1934).

44. United States ex rel. Brugnoli v. Tad, 300 Fed. 913 (S. D. X. Y., 1923), aff'd, 300 Fed. 918 (C. C. A. 2d, 1924); Cnited States or rel. Casimano v. Comm'r, 15 F. (2d) 555 (C. C. A. 2d, 1926); United States ex rel. Rumanow v. Flynn, 17 F. (2d) 378 (WV. D. N. Y., 1927). In United States er rel. Mandel $v$. Day, 19 F. (2d) 520,522 (E. D. N. Y., 1927), the court said: "The rule of this circuit is that, in the case of any alien ordered deported on the ground that at the time of his entry he was a person of constitutional psychopathic inferiority, the record must contain evidence as to the previous mental or medical history of the alien. Accordingly, where no reasuns whatever are assigned through or by virtue of which the decision was arrived at, the cannlusion is that the cause of the alien's psychosis could not have arisen subsequent to landing, and the court will refuse to uphold the action of the immigration authorities." Cinited States ex rel. Powlowec v. Day, 33 F. (2d) 267, 268 (C. C. A. 2d, 1929) wrerruled the d9atrine of Brugnoli v. Tod which required the clinieal history, indicating that the alien was insane on arrival, to be based on an examination of the alien, or on the alien's past history, when not deranged. The new doctrine is that a history based on the alien's conduct when actively deranged is sufficient, other facts heing probative, to show that the alien was insane on arrival.

45. 6 F. (2d) 468 (D. Conn., 1925).

46. 33 F. (2d) 267 (C. C. A. 2d, 1929). 
hospital in Connecticut for dementia praecox. One of his brothers was there with the same ailment. Deportation was sustained under the public charge clause on the ground that the disease was constitutionally hereditary, even though excitement might hasten its onset. Is it or not a fair psychiatrical statement that this individual might have lived his whole life through as a relatively normal person had it not been for the unusual stress of war? What kind of unusual stress, then, occurring within the United States might not also send an immigrant to a state hospital with dementia praecox or some other mental condition?

In the second case, a twenty-three year old Pole, who had entered in 1922, was sent to an insane asylum not quite four years later where his condition was diagnosed as "dementia praecox, hebephrenic." After a six months stay at the institution, the alien was discharged in the care of his brother. After the commitment, the Immigration Service had issued its warrant charging "constitutional psychopathic inferiority" at time of entry. During the proceedings, the superintendent of the hospital changed his diagnosis from "dementia praecox, hebephrenic" to "psychosis with psychopathic personality, discharged November 7, 1927, psychopathic personality - condition recovered." Three health surgeons at Ellis Island then examined the alien, found him free of mental defects, and declined to say that he had been suffering from any when he landed. The superintendent stood by his second diagnosis, and the deputy examiner of the Service, who had diagnosed "constitutional psychopathic inferiority," stood by his, saying, what physicians usually will not say, that the two diagnoses made no real difference, especially in so far as the clause in the law was concerned. With this point of view Judge Learned Hand agreed in an opinion which somewhat enlightens the subject:

"This unhappy man has, so far as we can see, been long detained over nothing more than a form of words ... The question is whether there is any evidence that shows him to have a mental makeup which falls within the phrase used in the statute. That was intended to include those who by nature were subject to insanity of one sort or another; that is to say, whose constitution was such that they had not normal mental stability. When that is so, their inferiority necessarily antedates their arrival here, because it is inherent in their nervous structure . . . [for this] we must accept the opinion of those formally qualified. It is enough that they shall be accredited in the customary way and honestly believe that the alien falls within the class ... If this results in too severe a test, and puts the fate of aliens wholly in the hands of any psychiatrist whom the Secretary of Labor is willing to accept, the remedy is with Congress. The whole subject is one of excessive uncertainty at best; whoever is fitted for the responsibility, it is certain that we are not; we must act upon what those tell us who carry the proper credentials." 47

47. 33 F. (2d) 267,268 (C. C. A. 2d, 1929). 
The mental defect cases, then, run along the line that aliens "without normal mental stability," as certified by physicians, ${ }^{28}$ may be held afflicted with "constitutional psychopathic inferiority" and so deported; or deported as public charges if they accept public hospital assistance within five years of entry, since the cause, "inherent in their nervous system," necessarily antedates their arrival in the United States. Whether this is sound, in the light of present day psychiatrical and psycho-analytical knowledge, raises questions too deep and too broad for discussion here, though, at bottom, the answers should be decisive of the law.: ${ }^{\text {t9 }}$

If disease is so treated, then what of the question of economic stress and, further, of the not unrelated question of crime?

The case of an alien whose business fails and who is therefore driven to public relief might appear simple. After all, the individual cannot control the economic sweeps of a nation. For that reason, possibly, the late Commissioner of the Immigration and Naturalization Service ruled that alien recipients of public relief would not fall within the interdicted class. ${ }^{50}$ This administrative ruling, however, has not yet been confirmed by the courts; and since causality is pressed so far in the mental cases, it might be fatal to rely upon it at all. The failed business man might have a long record of receiverships and bankruptcies and failures, and his individual history might show a definite inability to make a living anywhere. A reductio ad absurdum is not implied, but would such a man be "without normal economic stability?" And would this lack be "inherent in his nervous system?" Another Commissioner of the Immigration and Naturalization Service, whose feeling toward aliens was less lenient, might so rule and order.

48. For the requirements of these certificates see cases cited supra notes $42,43,44$. The shortest statement of the requirement is in United States c.5 rel. Pap3 v. Day, $45 \mathrm{~F}$. (2d) 435 (S. D. N. Y., 1930).

49. This is no place for a brash jump into psychiatry or psychoanalysis. But definitely there have been tremendous advances in the fields. Wrumss A. Write, Fons: Years of Psychiatry (1933); Mrencal Psychology (1931) c. 11; Tre Psichologrcal Factors In Disease. Definitely it is agreed that in every neurosis there is a general cause lying deep within the personality of everyone and a precipitating cause which may be almost anything. See Tye Editors. Fortune Mragazine, The Nervots Brenhiow: (1935) $3,13,29-30$. (The psychoses are major neuroses in which the confiet betwcen reality and the unconscious, the conflict which results in neuroses, has been resolved in favor of the unconscious and reality is disregarded by the individual).

50. Fiecds, The Refugee in the United States (1938) 51: "The Immigration and Naturalization Service of the United States, through the late Commissioner, Daniel W. AracCormack, ruled that receiving public relief did not constitute a tasis for claiming that the recipient had become a public charge, in the sense as used in the immigration laws." Comment, Statutory Construction in Deportation Cases (1931) 40 YALE L. J. $1283,1289, n .27$. "Assurance on this point has recently been given in a letter of the Commissioner General of Immigration stating that 'where lack of employment is the only factor which has placed aliens in needy circumstances, they incur no danger of deportation if they accept charitable aid.' Foreign Language Inforanatron Senvice, 8 I:itermieten RELEASE 16 (1931)." 
Some indication of the present view of one court on such a proceeding may be gleaned from United States ex rel. Mantler v. Commissioncr. A twenty-three year old alien was employed as a domestic. She had saved money and was adjusting herself well to the ways of the United States, so well in fact that she was guilty of improper relations with another lady's husband, and for that reason was sought to be deported as likely to become a public charge. The court decided she was not deportable, and in answer to the argument that she might be sent to jail for adultery and so was likely to become a public charge, said:

"Such conjecture or speculation would establish a rule that might endanger the continued residence of any immigrant. An immigrant might enter the country and be a failure in business or in securing gainful occupation, and by the same token it might be reasoned that he or she would be likely to become a public charge. It is possible that appellant might so demean herself as to come in conflict with the criminal laws, but we may not say that this is probable." (Italics supplied). ${ }^{62}$

Though here prediction be risky, it is likely that the ordinary and normal alien whose business fails, or who loses his job, will run no great danger in accepting public relief; but the alien with a record of failures may run a far more serious course.

The problem of crime must next be considered. It is curious that none of the reported cases holding deportable an alien who serves a prison term make mention of the cause subsequent to entry proviso in the statute. ${ }^{53}$ The plain reason for such silence is that the great majority of those cases do not involve the public charge clause. Deportation is there sought on the "likely to become a public charge" ground. But even in one of the few jail cases turning on the public charge clause, Ex parte Tsunetaro Machida ${ }^{54}$ the saving proviso was not discussed. It may be that the Service does not employ the public charge clause in the jail cases for the very reason that under it the alien would have opportunity to show that his predicament arose from a cause subsequent to entry. Such speculation, however, leads away from a more important facet of the question.

Suppose an alien motorist in a moment of gross inattention kills a pedestrian, is convicted of manslaughter and sentenced to the penitentiary. Will the public charge clause operate? On first blush it would seem not. A strong affirmative showing could be made under those facts that the cause of the accident was simply such momentary gross carelessness as might happen to anyone, and hence was a cause arising after the landing

51. 3 F. (2d) 234 (C. C. A. 2d, 1924).

52. 3 F. (2d) 234,235 (C. C. A. 2d, 1924).

53. See note 3 , supra.

54. 277 Fed. 239 (W. D. Wash., 1921). 
of the alien in the United States. It may be that for fear of such an argument the Immigration Service, in the case of In re Schiano Di Cola, did not prefer the public charge clause against the alien and relied only on that section of the law providing for deportation of any alien sentenced to imprisonment for a term of one year or more in this country for a crime involving moral turpitude. ${ }^{\text {so }}$

That is clear, but will the argument still be effective when the alien has a past driving record of shocking detail? The pertinent considerations are those raised in the other realms of causality. In addition, there may also be the question of whether an alien, sentenced to jail for reckless driving or for manslaughter, could be deported as falling within the class of those persons "likely to become a public charge" at time of entry. That question also arises in the mental defect and economic failure cases. It is created partly by the vague and comprehensive wording of the statute - "likely to become a public charge;" partly by an astonishing inversion of the doctrine of causality - from the fact that the alien after entry went to jail (or otherwise became a public charge) it is assumed that at the time of entry he was likely to go to jail (or become a public charge), the proof for the assumption then being the actual fact; and partly by the tendency of the Immigration Service to escape the saving proviso in the public charge statute by preferring instead the "likely to become a public charge" complaint - which contains no proviso relating to cause subsequent to landing.

II.

\section{Who Is Likely To Becone A Public Charge?}

"The most that can be said is that he had shown a propensity . . ." Judge Learned Hand

This clause is supposed to relate to the status of the alien at the time of entry. The case of W Wallis $v$. United States ex rel. Manmara ${ }^{57}$ illustrates sound operation under it. Two Italian aliens were held inadmissible for entry because the one, a man of 54 , was senile; and the other, a woman, was suffering from a grave cardiac valvular disease. It is clear that when the alien has physical defects of a nature that will affect his or her ability to earn a living, the "likely to become a public charge" clause fits the situation. Thus, one may agree with the decision in E.t

55. 7 F. Supp. 194 (D. R. I., 1934), discussed in Oprennemser, Recest Developments in the Deportation Process (1938) 36 Mire. L. Rev. 355, 369.

56. 39 STAT. 889 (1917), \& U.S. C. $\$ 155$ (1934). “. . . any alien who is hereafter sentenced to imprisonment for a term of one year or more because of conviction in this country of a crime involving moral turpitude..." In the instant case the crime was held not to involve moral turpitude.

57. 273 Fed. 509 (C. C. A. 2d, 1921). 
parte Hosaye Sakaguchi ${ }^{68}$ that a Japanese woman who had studied English (though she still had little knowledge of it) and was a graduate of a school teaching the sewing and arrangement of artificial flowers could not be held inadmissible as likely to become a public charge, simply because her proxy husband in this country refused to accept her and her brother-in-law was not legally responsible for her support. One may agree or disagree with Ex parte Rokiyi Tambara, ${ }^{50}$ which held a deaf alien inadmissible, even though the testimony showed that he had been previously employed at a salary of $\$ 4$ a day and that the manager of a concern in the United States had offered him a permanent position at livable wages; and all without denigrating the Immigration Service or the courts for applying the "likely to become a public charge" clause. But just what should be done with a mother, admissible by herself, although necessary for the best care of her inadmissible defective child? ${ }^{60}$ What should be done with unaccompanied children; ${ }^{61}$ or with a widow without visible means of support and her three year old son ${ }^{02}$ or with common laborers;" ${ }^{63}$ cause very considerable stretching of the "likely to

58. 277 Fed. 913 (C. C. A. 9th, 1922).

59. 292 Fed. 764 (W. D. Wash., 1923).

60. The question was raised in United States ex rel. Duner v. Curran, $10 \mathrm{~F}$. (2d) 38 (C. C. A. 2d, 1925), cert. denied, 271 U. S. 663 (1926), but dismissed as moot since the child had been sent back to Poland with an attendant by the time the case reached the court. If the parent or parents are inadmissible but the child is not, for all practical purposes the question of an unaccompanied child is raised. See note 61, itfra.

61. In Greenwood v. Frick, 233 Fed. 629 (C. C. A. 6th, 1916), the court remarked, obiter, that if the mother were not admitted, there was sufficient uncertainty of contint1ing support for the eight year old boy from the father to justify a finding that the child would fall under the "likely to become a public charge clause." In United States c.r rel. Azizian v. Curran, 12 F. (2d) 502 (C. C. A. 2d, 1926), the illiterate widowed mother was ordered excluded for illiteracy and the child was ordered excluded as likely to beconte a public charge since the relatives offering to take responsibility (uncles of the child) were not legally liable for support, the court adding, however, that it was hoped the child would be permitted to enter the United States under a public charge bond. United States ex rel. Berman v. Curran, 13 F. (2d) 96 (C. C. A. 3d, 1926), overruled exclusion of two unaccompanied children, respectively aged 12 and 13 , since the evidence showed they were coming to relatives whose worth was around $\$ 315,000$. United States $c \cdot r$ rcl. De Sousa v. Day, 22 F. (2d) 472 (C. C. A. 2d, 1927), overruled exclusion of an unaccompanicd boy who was coming to an uncle because there was no evidence that the promise of the boy's uncle to support him, though legally unenforceable, was not made in good faith, nor that the uncle was not financially able to keep his promise. The holdings are, to put it mildly, not uniform.

62. United States $c x$ rel. Smith v. Curran, 12 F. (2d) 636 (C. C. A. 2d, 1926), sustained exclusion, under the "likely to become a public charge" clause, of a widow and her three year old son on the ground that assistance offered by relatives and friends on whom the aliens had no legal claim for support was not sufficient, even though one relative was willing to file a public charge bond.

63. The famous decision on this point is that of Gegiow v. Uhl, 239 U. S. 3 (1915). Mr. Justice Holmes overruled the exclusion of illiterate Russian laborers by the Immigration Service, which felt that they were likely to become public charges since they were bound for Portland, Oregon, where industrial conditions were bad. The basis of 
become a public charge" notion. In certain cases, the Service appears to have gone in for entirely too much stretcling in contending that a healthy skilled workman was inadmissible because he had little money, and that young children were inadmissible because they would become public charges if their parents died. ${ }^{65}$

These are situations in which a drastic and ill-conceived enforcement of the laws has been attempted by the Immigration Service, though it must be remarked that in general the judiciary has behaved quite wholesomely. But when the Service tries to deport an alien, admissible at the time of entry, because of something the alien has done several years after entry, the elastic of cause and effect is snapped.

The cases are painfully ludicrous. They arise under the statutory language permitting deportation of an alien inadmissible at time of entry if the alien is taken into custody within five years of landing. ${ }^{0 S}$ The Department of Labor and many courts have apparently considered the language to mean that anything not nice done by an alien within five years of his landing may then be employed against him as evidence to show that at the time of landing the alien was inadmissible, as likely to become a public charge, regardless of the alien's actual status at the time he entered the United States. What warrant there is for such a construction of the statute gives added force to Professor Corwin's observation that what courts cannot prove they can always decide.

An alien who has committed a crime for which he may be arrested and jailed in this country may or may not be considered likely to become a public charge, depending upon what view the particular court will talie of the alien who is actually jailed. ${ }^{67}$ Further, the commission of crime may be taken as evidence showing a likelihood of the alien to become a public charge, not through imprisonment, but through delinquency - the habit of not endeavoring to earn an honest living. Both points were

the decision was that the "likely to become a public charge" clause orcurred in the statute between "paupers" and "professional beggars" and hence required for exclusion the same permanent physical fact as was needed to exclude those classes, and not a temporary overstocking of the labor market. The Immigration Act of 1917 attempted to overcome this decision by changing the situs of the "likely to become a public charge" clause "in order to indicate the intention of Congress that aliens shall be excluded upon said ground

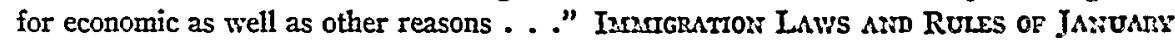
1,1930 (U. S. Gov't Printing Office, 1935).

64. Ex parte Sturgess, 13 F. (2d) 624 (C. C. A. 6th, 1926), dismissed the contention.

65. See United States $e x$ rel. Duner v. Curran, 10 F. (2d) 38 (C. C. A. 2d, 1925), cert. denied, 271 U. S. 663 (1926). The record is destitute of the slightest evidence that these children were likely to become public charges. "It is true that by the death of their parents they might become such, but so would any children of like age. It is impossible that the statute meant to exclude all such children." United States cr rcl. Duner v. Curran, supra, at 41.

66. See pp. 18-19, supra.

67. See pp. 20-22, supra. 
stressed in United States ex rel. Freeman $v$. Willians. ${ }^{08}$ The alien there had twice been convicted of assault in Great Britain, had been indicted for larceny from the trial of which he had fled, had committed robberies in Austria, had sold fake gems in the United States, and habitually consorted with a band of thieves. The court felt that the alien would not only soon be involved in crimes in the United States but that, even when not in prison, he would live at the expense of the community. On much the same theory, there are decisions that aliens addicted to gambling, who do not engage in honest industry, are deportable as likely to become public charges at the time of entry. ${ }^{69}$ With that introduction the absturd cases are brought into focus.

In one of them, a proceeding to deport a forty-two year old woman, nurse by trade and preacher by inclination, was actually brought on the theory that the alien had excited the resentment of a Mrs. S. by living in the same house with Mr. S. (who had separated from his spouse), taking bicycle lessons from him, and becoming so familiar with him that Mrs. S. in her contemplated suit for a separation might include the alien as a co-respondent, or might sue her for alienation of affections (thits possibly depriving the alien of her property by a judgment), or might forward a criminal prosecution against the alien (thus possibly lodging her in jail). The court, however, refused to put up with this nonsense. ${ }^{70}$ In another case, where the alien, though married, stopped at a hotel with a woman not his wife, occupied the same bed with her, and, as the court opined, "conclusively did have sexual intercourse with her," deportation on the "likely to become a public charge" ground, as well as for illegal entry, was sustained. ${ }^{71}$ A similar ruling was enunciated in a bigamy case. ${ }^{72}$

The grating asininity of these holdings was exposed in E.r parte Costarelli. ${ }^{73}$ Shortly after an Italian alien had entered this country in 1920, he sent for his wife and two children with whom he lived until 1922 when he deserted, posed as a single man, and married another. Later he returned; found his legal wife in an insane asylum and his children in a destitutes' home; confessed all to the bigamous wife who accepted the children, and then, when the legal wife died, the two were married and the family began to make the most of a scrambled life. At this point the ever-alert Immigration Service arrested the man for deportation on the ground that, although admissible in 1920 when he had entered

68. 175 Fed. 274 (S. D. N. Y., 1910).

69. Lam Fung Yen v. Frick, 233 Fed. 393 (C. C. A. 6th, 1916), cort. denict, 242 U. S. 642 (1916); cf. Ng Fung Ho v. White, 266 Fed. 765 (C. C. A. 9th, 1920), cort. grantcd, 254 U. S. 628 (1920), aff'd in part and rev'd in part, 259 U. S. 276 (1922).

70. Ex parte Mitchel1, 256 Fed. 229 (N. D. N. Y., 1919).

71. Ex parte Reeves, 292 Fed. 766 (W. D. Wash., 1923).

72. Ex parte Britten, 293 Fed. 61 (W. D. Wash., 1923).

73. 295 Fed. 217 (D. Mass., 1924). 
the United States, he had later committed the crime of bigamy for which he might be jailed, and therefore at the time of entry in 1920 he was likely to become a public charge. The court, in an opinion not sharp enough by half of what it could have been, remarked that the contention was absurd that by actions subsequent to entry the alien in the case before it, was, at time of entry, likely to become a public charge. In the same year, the Circuit Court of Appeals for the Second Circuit took a similar stand and refused to deport a twenty-three year old girl because she had, some time after entry, been guilty of adultery. ${ }^{72}$

Yet District Judge Hutcheson, presumably cognizant of these eases. refused habeas corpus to a Mexican man and woman who had been illegally living together in Texas for fifteen years. ${ }^{\text {i5 }}$ This case was slightly different on the facts, since the Immigration Service had arrested the aliens as likely to become public charges after one of their frequent trips from Laredo, Texas to Mexico and back. The learned judgre. faced with the "entry" rulings and with evidence that the man had orivinally "imported" the woman to live with him, apparently felt impelled to his decision, although he himself protested against it. ${ }^{\text {i0 }}$

Of all the cases dealing with the "likely to become a public charge" clause, the Costarelli decision is almost the only one setting out sharply the conditions under which that clause should operate. The clause, it cannot be too strongly emphasized, refers to aliens as of the time they enter the United States. To pervert the clause, as the Immigration Service and some courts have done, into holding aliens deportable as of the time of entry on the ground that after entry they committed a crime, or took relief, or did other undesirable things, is an unpardonable inversion cutting the statute into paper dolls. Nevertheless, there can he one exception to this: if actions subsequent to entry show a cause existing prior to entry, then, plainly, at the time of landing the alien was likely to become a public charge. And that brings back the question of whether the alien sentenced to jail for reckless driving or for manslaughter, or whether the alien who has failed in business, can be deported as a person who was at the time of entry within the proscribed class.

If the alien's past driving record is clean, there should be no doulit but that the cause does not reach as far back as the time of entry. If the alien's record is a spate of offenses, say, with a death or two un it, the question is honestly debatable. It is equally debatalile in the case of the alien whose business has smashed. If the alien has a long record of

74. United States $c x$ rel. Mantler v. Comm'r, 3 F. (2d) 234 (C. C. . 1. 2d, 1924).

75. Ex parte Rodriguez, 15 F. (2d) 878 (S. D. Tex 1926).

76. Id. at 879. "I cannot refrain from saying, however, that such a literal, drastic, and harsh application of the law. . . was not, in my opiniun, intended by the iramers of it, since under the undisputed facts these persons have been in every resriset as man and wife, and would be under the laws of Texas united in a cummun-law marriage, but for the legal impediments of their prior marriage." 
failures and is the type of person who has always been, and always will be, an economic misfit, there may be a very real issue on the "likely to become a public charge" complaint.

\section{CONCLUSION}

"I am sorry, my lords, that my young friend so far forgot himself as to treat your lordships with disrespect. $\mathrm{He}$ is extremely penitent, and you will kindly ascribe his unintentional insult to his ignorance. You will see at once that it did originate in that: he said he was surprised at the decision of your lordships. Now, if he had not been very ignorant of what takes place in this Court every day; had he known your lordships but half so long as I have, he would not be surprised at anything you did."

John Clerk, later Lord Eldin

The upshot of this matter of the alien and the public charge clauses is not particularly edifying.

True, changes within and without the present statutes are necessary. Outside of the legislation now on the books, the tangled state of the law on imprisoned aliens might be straightened. Within the statutes, amendments to clarify what is meant by public charge, who are public charges, what is public assistance, are exigent. Within the statutes; amendments to crystallize the vagueness of "likely to become a public charge," to remove the asinine use of that phrase in cases where the actions complained of occurred years after entry and bore no relation to the status of the alien at the time of entry, to prevent application of the "likely to become a public charge" clause in cases where the public charge section is sought to be avoided because of the saving proviso there; all these are pressing necessities, but, even if achieved, might still be fruitless.

For the motto of the Immigration Service, in these cases, has seemed to be revenge; revenge for a fancied wrong done the state by the alien who becomes a charge upon public facilities, or who breaches the immigration laws willy-nilly or inadvertently. And although here and there judges decide causes in what from the laic point of view is a common sense way, many either wring their hands in written lament and implore the Department of Labor not to be mean, or grimly go through with the job of setting their seals upon draconic, literal, and unplanned enforcement of irrational immigration measures. It is said that the Immigration Service and the Department of Labor within the past six years have become more humane. Perhaps so. Certainly there have been marked changes for the better. The Department no longer merits calumny. But the laws on the books are still the same. Those statutes need a thorough and reasoned overhauling in view of present national and world-wide societal phenomena. 